\title{
The Determinants of Intra-Party Elections in Pakistan: A Study of Major Political Parties
}

\author{
Shaukat Ullah ${ }^{1} *$ \& Amna Mahmood ${ }^{2} \&$ Surat Khan ${ }^{3}$ \\ 1. Department of History \& Pakistan Studies, International Islamic University, Islamabad, Pakistan. \\ 2. Department of Politics \& International Relations, International Islamic University, Islamabad, Pakistan. \\ 3. Department of Political Science, Bacha Khan University, Charsadda, Khyber Pakhtunkhwa, Pakistan.
}

Received: June 28, 2020

Published Online: December 22,2020

\begin{abstract}
The article covers the need and importance of intra-party elections in Pakistan. It is an essential mode to observe internal democracy in a political party and a gateway to promote ordinary members from bottom to top in leadership position. Intra-party democracy played key role in the production of new leadership from the grass-roots level. The intra-party democracy is significant for the stability of a political system. It also engaged the party members to defend and explain the party policies in the right way. Hence, intra-party democracy provides a leading role to all registered members to participate directly or indirectly in the process of decision making. In Pakistan, political parties and state politics revolve around personalities and some monastic families. Even mainstream political parties of Pakistan avoided intra-party elections and leading leadership comes from the top through direct nomination. In this way all the portfolios within the parties are conformed. This paper further explores that what are the challenges faced by a real and authentic intra-party elections in Pakistani political parties and why political parties avoided an intra-party election. The study concludes that in practice the grass-roots members of political parties are ignored in all crucial decisions making within the party.
\end{abstract}

Keywords: Political Parties, Party Members, Political Leadership, Dynastic Families, Dynastic Politics, Party Elections, Political Challenges.

\section{Introduction}

Political parties play a vital role in political socialization through involving citizens in the political process and promoting democratic values. In this context their role is decisive in building political institutions in a society. Internal elections at all levels in political parties are one of the most essential and leading indicators of a democratic political culture. Holding free and fair intra-party elections determines the direction for a better national democratic culture. The concept of intra-party democracy is that the political parties follow democratic principles in their internal party affairs. Leadership is elected by the party workers at all the levels on merit by following the clearly defined democratic principles and there is no room for appointment from top level of leadership. All party members are required to participate in all internal party decision making process (Scarrow, 2005). For that purpose, there should be an effective internal mechanism of political parties to take decisions with mutual deliberation and discussion. The most crucial challenge is the election of the party president for which the candidate selection process should be transparent. Senior party members may apply to be 
party chairperson. After the selection for top party offices, the electoral process of various positions in the party should be initiated (Sandri \& Amjahad, 2015).

Due to the dominance of undemocratic culture in state politics, political parties in Pakistan remained weak and inconsistent. However, the absence of genuine intra-party elections has been highly de-motivating factor that gave rise to the politics of personalities and families, in turn weakening the party internally. In fact, the competition and participation are significant elements of the democratic process. This study examines the intra-party elections and its mechanism in Pakistan. How far the intra-party elections meet the international standards of similar process in other liberal democracies. It also examines the key challenges in the way of intra-party elections in the major political parties of Pakistan. However, study covers data of only 6 political parties of Pakistan.

\section{Literature Review}

The early elections are very popular among European parties which have adopted the American model and have become accustomed to political environment of their countries (Sandri \& Amjahad, 2015). In these countries the party constitutions allow for the selection of candidates and provide specific rules for intra-party elections to promote competition among the politicians. To practice internal democracy, the political parties should be committed to democratic cause (Scarrow, 2005). There are many requirements within a party organisation such as elections of leadership at various levels within the party, making the necessary decisions on policy matters through direct participation of party members. The conduct and transparency of these functions determine the relationships between party leadership and ordinary members. Many European political parties have recently debated whether to hold open primary elections for candidates or not (Sandri \& Amjahad, 2015), as exercised by political parties in many states of the US.

Intra-party democracy is still a contested concept both in terms of meaning and operationalisation. It is about the internal distribution of power within a political party (Cross \& Katz, 2013), which requires at least some degree of participation by the "political party on the ground' in the selection of leadership for the party's central offices (Katz, 2014). The significance of political parties for political systems, especially for democratic settings, is broadly discussed and described by Scarrow (2005), Hazan \& Rahat (2010), Cross \& Katz (2013). Besides, the importance of intra-party democracy for various outcomes, inside and outside the parties themselves, has attracted much scholarly attention (Scarrow, 2005; Cross \& Katz, 2013). Intra-party democracy is a link between state and society. It is understood as a mode of implementation of a social contract between the constitution and members of a political party, for the engagement of later in decision making process within the political parties (Katz \& Cross, 2013; Bolin et al., 2017). In this way, the intra-party democracy allows party members to deliberate and form their preferences according to their needs. It realizes the aggregation of these preferences within the political party. It is a source of legitimacy for major decisions about recruitment of leaders (from contesting candidates), nominating candidates for general elections, and other policy decisions (Allern \& Pedersen, 2007; Bolin et al., 2017; Teorell, 1999).

Intra-party democracy is a mode of change as it challenges the status quo (Robert, 1976) by rotating the power among party factions and providing an opportunity to dissident groups who want to change the current political structure (Brady, 1988). However, the intra-party 
elections in Pakistan have been a strange phenomenon. The major political parties, such as the Pakistan Muslim League-N (PML-N), the Pakistan Muslim League-Q (PML-Q), the Pakistan Peoples' Party Parliamentarian (PPPP), the Jamiat-e-Ulama-e-Islam-F (JUI-F), the Muttahida Qaumi Movement (MQM), the Awami National Party (ANP) and the Pakistan Milli Awami Party (PMAP) consider the intra-party election as a mere formality (Rehman, 2016). The leaders from prominent families like Sharifs, Bhuttos, Chaudhrys, Zardari's etc., have been controlling the top positions and all policies of their respective parties at the national level. In case of the regional political parties, the Khans, Sardars, and Waderas (all feudal, landed aristocracy) have traditionally exercised a strong grip over the workers to curtail their right to choose their party leaders independently.

According to Pakistan's Political Parties Order 2002, all political parties must hold intra-party elections at a specified time. The framework and procedure for holding elections within the parties has been set out in this order. This ordinance stated that the party presidents and other leadership would be chosen from the bottom to the upper level, based on democratic principles of transparency (Pakistan Political Parties Order, 2002). With the unanimous approval of Parliament's electoral reform committee, it was decided that all the political parties would hold intra-party elections within six years instead of four, with two-year concessions (Mughary, 2017). Pakistan's Institute of Legislative Democracy and Transparency (PILDAT) presented reports on internal party democracy in Pakistan in 2014 and 2015. However, these reports do not focus on the process of internal elections, the major challenge to the internal party elections in Pakistan. The concept of internal party elections in Pakistan is not yet worth attention. Nonetheless some of the political parties such as Jamaate-Islami (JI), the ANP and Pakistan Tehreek-e-Insaf (PTI) believe in intra-party elections, giving varying levels of freedom to their party workers.

\section{Methods and Data}

Intra-party democracy is a vast area of study and the intra-party elections are the leading indicators of intra-party democracy. Scholars like Rizwan et al. (2016) and Tariq et al. (2016) have worked on the intra-party democracy in Pakistan. However, these scholars did not compare the intra-party election in major political parties of Pakistan. The main object of this study is to explore as to why the political parties avoided a genuine intra-party election. The unit of investigations is the determinants of the intra-party election. This study followed a qualitative research approach to evaluate the practices of intra-party election in major political parties of Pakistan and why the ordinary members are denied their democratic rights within their own party raising slogans to establish democracy at the national and provincial level. Moreover, this study followed the rules (table-1) of inclusiveness and exclusiveness (Scarrow, 2005; Wauters, 2014) to assess the most democratic process of intra-party elections in the major political parties of Pakistan. The data is collected from secondary sources such as books, articles, reports, conference papers and daily newspapers. The primary data is collected from websites of Pakistani political parties, constitutions of various parties, and indepth interviews with Pakistan-based think tank experts.

Table 1: Intra-Party Election Inclusiveness and Exclusiveness

\begin{tabular}{|l|l|l|l|l|}
\hline \multicolumn{2}{|c|}{ Inclusiveness } & \multicolumn{3}{c|}{ Exclusiveness } \\
\hline Open Primaries & Closed Primaries & Party Conferences & Parliamentary Party & Party Elite \\
\hline Any interested & All party & A delegation representing & Members of & Small \\
voters & members & party members & National Legislature & Group \\
\hline
\end{tabular}




\section{Analysis and Discussion}

The study focuses on the intra-party elections in Pakistan according to the process required by Pakistan's Political Parties Order 2002 under which intra-party elections are necessary to be held at the appropriate time. However, to fulfil the requirements of the Election Commission of Pakistan, most of the political parties appoint the head of the party along with provincial and regional presidents through an indirect election process. This study found that the actual methods of intra-party elections are not according to the procedures given in Political Parties Order thus raising a serious challenge to authenticity of the whole process of intra-party elections.

\subsection{Procedures of Intra-Party Election in Pakistan}

PTI first time conducted the intra-party elections in 2012-13, and the party members participated in a large number. At that time, it was a remarkable step against non-democratic political culture the prevailing within the Pakistani political parties. The procedure of last intra-party election held in PTI was different from the previous one. The intra-party elections of PTI in 2012 were held through the secret ballot and one member one vote. However, in 2017, Imran Khan, Chairman PTI, brought his own panel of candidates and Naik Muhammad Khan, his contestant, led another panel. These panels included the chairperson, general secretary, regional heads in Punjab and Khyber Pakhtunkhwa and provincial heads in Sindh and Balochistan. The party president, along with the entire office bearers, was elected through a short message through mobile, by the registered party members. Traditionally the political parties in Pakistan have been observing weak internal democratic norms especially in terms of conducting fair intra-party elections. Imran Khan, the Chairman of PTI, also followed the suit in 2017 despite his long-held claims of change in Pakistan's political culture (Yasin, 2017).

Although PTI spent millions of rupees on the development of software for intra-party elections and registered its workers along with their mobile phone numbers, however the liberty to choose the candidate of their choice remained restricted (Hussain, 2017). PML-N is another major political party in Pakistan. The central bodies of the PML-N consisted of the Convention, the Council, the Central Working Committee and the Central Parliamentary Board. The provincial presidents of PML-N were elected unopposed in 2012, along with the central party president who was also elected unopposed. The procedure of intra-party election of PML-N is straight forward. The party general council consist of 2000 selected members, appointed by the party president, general secretary, six vice-presidents, finance secretary and information secretary (PIDAT, 2016). After the disqualification of Nawaz Sharif by the Supreme Court of Pakistan in Panama leaks case, he was also barred to be party president. Therefore, his brother Shahbaz Sharif was appointed as party president unopposed in March 2018 (Malik, 2018).

In case of Pakistan Peoples' Party (PPP), Z. A. Bhutto founded this part in 1967 and remained its life time chairman (Khan et al., 2017). After his execution in 1977, his wife, Nusrat Bhutto became leader of the party formally elected by a meeting of the Central Executive Committee (CEC) and remained chairperson till 1984. She shared this position with her daughter Benazir Bhutto as co-chair of the party. Hence, after Nusrat Bhutto, her daughter Benazir Bhutto became the chairperson of the party (Mushtaq et al., 2013; PILDAT, 2016). She was assassinated in 2007 since then the party is being led by her husband and son, 
Asif Ali Zardari and Bilawal Bhutto Zardari as co-chairman and chairman respectively based on a so called political will of Benazir Bhutto (Mughary, 2017). Therefore, the present head (chairman) of PPP is elected unopposed without competition and participation of party members in any electoral process.

JUI-F is a religious, political party, and its party constitution requires elections all these offices after every three years. At each tier, there are three distinct bodies: the Majlis-eAmoomi (General Council), the Majlis-e-Shura (Consultative Council) and the Majlis-eAmla (Central Working Committee). Majlis-e-Amoomi (General Council) is an internal decision-making body regarding the constitution and elections. It elects 30 members at the tehsil (town) level. These 30 members elect other members for the district level, and the District members elect one member for the province. The provincial members elect one for central representation (International Crisis Group, 2011). Under the constitution of JUI-F, at the centre and provincial level, the Chief (Amir) and the General Secretary should be elected, while now all these main portfolios are nominated (PILDAT, 2016).

$\mathrm{JI}$ is a religious political party. The intra-party elections are held in JI through secret ballot and one member one vote. JI holds intra-party elections every three years, but according to the party constitution, the term of office for the president (Amir) in the centre is five years (Article 17-5). The central Consultative Council proposed three names for the election of party president. According to the party constitution, (JI Constitution, Article, 17-3) all the registered members have the right to vote and, elect the party president through a secret ballot (Constitution of Jamaat-e-Islami Pakistan).

ANP is a regional nationalist political party. The main slogan of ANP is the protection of the rights of Pakhtuns in Pakistan. According to the constitution of ANP the procedure of intraparty election is: all office-bearers of the Central Council, Central Executive Committee, Central Cabinet, and all other Party office-bearers shall be elected for four years. However, the present president of party has been elected unopposed i.e., without competition and participation of party members/workers.

The table-2 shows the process of intra-party election in the major political parties of Pakistan. JI and PTI have followed the most inclusive method. They used closed primary in the intraparty election for the party president. The competition was done between two panels in PTI and among three candidates in JI for the party presidents. The party members participated in the intra-party election through one member one vote. However, the other political parties followed a very exclusive method because there was no competition between/among the candidates and no participation of party members in the intra-party election for the party president.

Table 2: Election Status of the Present Presidents of the Political Parties

\begin{tabular}{|c|l|l|c|l|}
\hline No. & Party Name & Numbers of Candidates & Participants & Election Status \\
\hline 1 & Pakistan Tehreek-e-Insaf & Two Panels & Party Members & Competition \\
\hline 2 & Pakistan Muslim League-N & One & --- & Unopposed \\
\hline 3 & Pakistan Peoples Party & One & --- & Unopposed \\
\hline 5 & JamiatUlema-e-Islam-F & One & --- & Unopposed \\
\hline 5 & Jamaat-e-Islami Pakistan & Three & Party Members & Competition \\
\hline 6 & Awami National Party & One & --- & Unopposed \\
\hline
\end{tabular}

Source: coined by author. 


\subsection{Challenges to Intra-Party Election in Pakistan}

The intra-party election may involve and election process of a wide range of political party officials as well as candidates for different levels of political representation such as national, regional, local, and sub-local level. For each level and position, a different set of specific challenges can formulate, although some challenges seem to cover all elections (Salih, 2006). For example, the main challenges which are faced by a valid and democratic intra-party election in Pakistan: are the dominance of elites, non-competitive leadership elections, discriminatory selection of candidates, nepotism, and succession of dynastic leadership and absence of free and fair election.

\subsubsection{Dynastic Leadership}

The politics of kinship networks in Pakistan, especially and generally South Asia, is firmly close in the politics of clientelism, which in turn closely related to caste, ethnicity, and identity. Clan, tribe, caste, and baradari (sub-caste) play a substantial role in electoral contests in general and intra-party elections. These ties are also allowed the political family's hold on resources and the passing on of these resources as a legacy to new generations of family members (Dodd, 1976; Mushtaq et al., 2013). The mainstream Political parties in Pakistan have become stagnant with the same leaders, voices, programmes, and propaganda. Their leadership patterns do not allow the fresh recruitment of leaders from new social and middleclass party members. Only the younger generation of the traditional elites can replace them at the top level. The dynastic quality of leadership is a big handicap for the democratisation of political parties from within, one of the necessary conditions for any parliamentary system to succeed at every level (Akhtar, 2008).

The succession based leadership at top level of political parties is a root cause of not holding intra-party election. Even, if the elections are held, they are just as a formality, therefore, the common party members are alienated as they already know the results. This process has remained the practice in PPP, PML-N, ANP, JUI-F and now in PTI as well. The leadership of PPP moves around Bhutto family since its establishment. ANP is led by the Bacha Khan family i.e., his son Abdul Wali Khan (founder of ANP) and now Asfandyar Wali Khan. PML-N was established by Mian Nawaz Sharif and he became the first president. The party leadership is still in control of Sharif Brothers, and now Nawaz Sharif's daughter Maryam Nawaz has been preparing to lead PML-N in future. JUI-F was led by Mufti Mehmood and after his death, his son Mulan Fazlur Rehman is leading the party as JUI-F till date (PILDAT, 2016). They never desire to implement intra-party democracy and holds internal elections in political parties.

Beside all these major dynastic political parties, Jamaat-i-Islami, a religious political party holds intra-party elections properly and elects the party presidents of all tiers in a democratic way. That is why, mostly, the party's central presidents are changed/retired after completing their terms. PTI also holds an intra-party election for the post of party president and other party positions.

According to Clause (2), Section 11, of Pakistan's Political Parties Order 2002 every party member, subject to the provisions of the party's constitution, shall be provided with an equal opportunity of contesting election for any party office including that of the party head (president). Participation and competition are the most important modes of leadership 
selection from bottom to top level through the intra-party election (Hazan \& Rahat, 2010). If the political parties do not plan replacement at various leadership positions, it may cause a chaotic situation as the term of a leader ends. Also, if the political parties do not develop their pipeline of leadership on sound footings democratic values, norms, practices, ideology, and vision, it would fail to grow into a sustainable entity worthy of the trust they demand from their electorates (Noe et al., 2007). Intra-party democracy promotes new leadership as well as provides backup leadership from bottom to top level at political parties.

\subsubsection{Decentralisation (Division of Power)}

The intra-party democracy is about internal power sharing arrangement within the members of political parties. In recent decade fingers are being raised that internal power of parties has been enjoyed by a single family or a small group of elites and the political workers are just used to make sacrifices (Cross, 2013). The scholars argue (Poguntke \& Webb, 2005) that with the permanent elites in party leadership positions, the prospects of participation of ordinary members in decision making process become minimal. In hereditary and dynastic leadership, all the powers move around in a single leader, and he makes all the critical decision alone.

The decentralisation within political parties means to give party members and their representative more power in party's internal affairs and decision-making. The powers should be divided among different officeholders, owing to this the dominance of a single leader would be ended. The party members have the right to select candidates for internal party positions and parliamentary elections according to their merit from their constituency (Hazan \& Rahat, 2010). In fact, it would hard for the party president to avoid an elected provincial, regional and district level president of his party while making decisions of allocation of seats etc., therefore they avoid an intra-party election and continue to enjoy their unchallenged position within the party (Mehboob, 2019).

\subsubsection{Unawareness of Party Members}

Mostly political parties in Pakistan are very weak in internal democracy as well as the lack of technical methods to maintain their organisation and engaged their members to democratic process through intra-party activities (Mahmood, 2003). The party members do not have enough knowledge about intra-party democracy and their rights as a party member. The party leadership and elite class maintain their role in the internal decision-making process; the members are utilized by party leaders during the election campaign for hanging party banners and posters. The knowledge economy, education and research are essential pillars for the growth of a nation. A nation, where the literacy rate is less than 50 percent political parties should initiate to promote education by starting it from within their internal organisations (Raza, 2012).

In modern democracies of the West, the political parties, their leaders, and members continuously face new issues and questions. They must take positions because of day-to-day developments and social changes. This is part of political socialization. However, it becomes more important when it is directed towards the youth of the party (Hofmeister \& Grabow, 2011). The intra-party democracy develops where decision making is preceded by open debate and exchange of arguments among equal, free, and rational agents. The argument is that there should be only a well-informed membership that can be able to hold party 
leadership accountable. There are two critical prerequisites for a deliberative party atmosphere; the first one is information regarding the status of the party should be available to all members preceding to discussions and the second is, the knowledge of party statutes should not be limited to the party elites. It should generally available to the party membership (Mimpen, 2007).

\subsubsection{Primaries and Party Unity}

The intra-party elections create internal conflicts among the supporters of different candidates who contest the election for the party offices. Therefore, many major political parties of Pakistan avoided intra-party elections. Intra-party elections create many groups and subgroups within the political parties because every candidate has many supporters. However, it is perilous for the general election. Scarrow (2005) argues that, too much internal democracy and de-centralization of the power weaken the leadership and makes it difficult for the party to follow its internal discipline and keep electoral promises.

The party courts are established as an internal dispute resolution committee. These committees mostly have to deal with the disputes about membership and voting rights, other procedural issues or sanctions against members whose behaviours are not in line with the party discipline and who may have violated the statute or the party's fundamental values (Hofmeister \& Grabow, 2011). PTI held an intra-party election in 2012 for the selection of candidates for general elections 2013. This created many internal conflicts among candidates and members. Therefore, PTI held next intra-party elections in 2018 through a mobile message between two panels to save the party from internal conflicts which was created during the 2012 intra-party elections. JI is the most organised political party, but still, it does not allow the campaign for the party president (Ameer) elections because it is dangerous for the party unity (Mehboob, 2019).

\subsubsection{Check and Balance}

The political institutions cannot function in its true spirit without an effective system of checks and balances. These checks can be institutional, formal, or informal and outside the formal political process. The institutional checks come from the party organization, democratic functioning within the party itself and party discipline. Then outside the party from an active opposition and the separation of powers. Under Section-11 of Political Parties Order, 2002, it is a legal requirement that all political parties shall hold intra-party elections after every four years. Under Section 12, the party leader of each political party is required to submit a certificate duly signed to the Election Commission that the elections were held following the constitution of the party and under provisions of this law.

The party head is also bound under the law to submit the election results, including the total number of votes cast and the number of votes secured by each contestant, for all party offices. However, the Election Commission of Pakistan has never questioned the transparency of intra-party polls of any political party. The list of 'elected' party office bearers accepted without raising any objection (Pakistan Political Parties Order, 2002). The former Secretary of Election Commission of Pakistan, Kanwar Dilshad said that it was the duty of the Commission to ensure that the intra-party polls in political parties are held as per rules and in a transparent manner (Hussain, 2017). 


\section{Conclusion}

Political parties are the primary institutions for establishment of a democracy. Both are essential for each other, for a smooth and accountable democratic system. The central concept of intra-party democracy is that the political parties would be internally democratic in the selection of candidates, selection of party leadership, internal policymaking and decision making. All the decisions will be made on the consent of the party members according to democratic principles. The intra-party election is a process for the selection of party leader and other party officials based on one member one vote. The party policies and procedures shall be clear about the rules of intra-party elections to choose party leader and candidates' selection to encourage competition among politician.

Although the intra-party elections are mandatory for political parties according to Pakistan Political Parties Order 2002, but there were many challenges to these elections in Pakistan. Owing to these challenges political parties only fulfil the election commission's criteria. Election Commission of Pakistan has no check and balance on political parties and accept undemocratic intra-party elections without raising any questions and objections. The mainstream political parties of Pakistan have the tradition of dynastic leadership and leaders come through nomination from a dominant family from generation to generation. This practice is followed in PPP, PML-N, ANP and other main stream political parties of Pakistan except a few. Only few political parties hold intra-party elections, and exercise decentralisation in its internal affairs such as JI, ANP and PTI.

Pakistan is a developing democracy and literacy level is still very low. Majority of the party members are uneducated, and are not aware of their rights to insist on intra-party elections for changing leadership from bottom to top level. The political parties of Pakistan must involve their party members in the entire important decision making, especially in the elections of party presidents. The direct participation of party members in the entire party affairs improves the affiliation of common members with their party decisions and they would be able to defend their parties on every forum. However, intra-party elections also create internal conflict among party members and candidates who contest the elections. The major finding of this study is; JI has the more inclusive system of intra-party election and the top leadership changes regularly and comes from the different families and different areas of the country through an electoral process. PTI also has an inclusive system of intra-party election for the selection of party president while in other major political parties mostly the leader comes from the same bloodline.

\section{References}

Akhtar, N. (2008). Pakistan's undemocratic political culture. In $17^{\text {th }}$ Biennial Conference of the Asian studies Association of Australia in Melbourne 1-3 July 2008. https://citeseerx.ist.psu.edu/viewdoc/download?doi=10.1.1.539.9475\&rep=rep1\&ty pe $=$ pdf

Brady, D. W. (1988). Critical elections and congressional policy making. Stanford University.

Dodd, L. (1976). Coalition in Parliamentary Governments. Princeton University.

Hazan, R. Y., \& Rahat, G. (2010). Democracy within parties: candidate selection methods, and their political consequences. Oxford University. 
Hofmeister, W., \& Grabow, K. (2011). Political parties: functions and organisation in democratic societies. Konrad Adenauer Stiftung.

Hussain, D. (2017, April 16). PTI determined to hold intra-party polls on time. Express Tribune. $\quad$ https://tribune.com.pk/story/1384960/pti-determined-hold-intra-partypolls-time/

Hussain, M. (2017). Who would ensure transparency in intra-party polls? The Nation. https://nation.com.pk/10-Jan-2017/who-would-ensure-transparency-in-intra-partypolls

International Crisis Group. (2011). Islamic parties in Pakistan, Asian Report No. 216. https://www.crisisgroup.org/asia/south-asia/pakistan/islamic-parties-pakistan

Khan, A., Khan, T. M., \& Rehman, A. U. (2017). Government-opposition relations amidst the provincial autonomy during Bhutto regime. Journal of the Research Society of Pakistan, 54(2), 41-52. http://pu.edu.pk/images/journal/history/PDF-FILES/04Paper_54_2_17.pdf

Malik, H. (2018, February 21). Supreme Court bars disqualified Nawaz Sharif from heading PML-N. Express Tribune. https://tribune.com.pk/story/1640783/1-sc-reservesjudgement-election-act-case/

Mughary, I. (2017, January 08). PPP Faction hold intra-party polls to award top slots to Zardari and Bilawal. Daily Dawn. https://www.dawn.com/news/1307199

Mehboob, A. B. (2019). Personal interview by in lead author. Ahmed Bilal Mehboob is the president of Pakistan-based think tank PILDAT and columnist for the Daily DAWN. https://pildat.org/about-us

Mahmood, S. (2003). Pakistan: political roots and development, 1947-1999. Oxford University.

Mimpen J. (2007). Intra-party democracy and its discontents: democratisation in a volatile, political landscape. Netherlands Institute for Multiparty Democracy, The Hague. http://citeseerx.ist.psu.edu/viewdoc/summary?doi=10.1.1.581.8569

Mushtaq, A. Q., Ibrahim, M., \& Kaleem, M. (2013). Dynastic politics in Pakistan. International Journal of History and Research (IJHR), 3(4), 1-12. http://www.tjprc.org/publishpapers/2-42-1375764356-

1.Dynastic\%20Politics.full.pdf

Noe, R. A., Hollenbeck, J. R. Gerhart, B. Wright, P. M. (2007). Developing employees for future success (Chapter-9). Fundamentals of Human Resource Management $\left(2^{\text {nd }}\right.$ ed.). Tata McGraw-Hill.

PILDAT, (2016, February 1). Internal democracy of major political parties of Pakistan 2015. Report No. pp-015. Pakistan Institute of Legislative Development and Transparency. $\quad$ https://pildat.org/political-parties1/internal-democracy-of-majorpolitical-parties-of-pakistan-2015

Poguntke, T. \& Webb, P. (2005). (eds). The presidentialization of politics: a comparative study of modern democracies. Oxford University.

Putnam, R. (1976). The Comparative Study of Political Elites. Prentice-Hall.

Raza, B. (2012). A baseline study on organisational practices and effectiveness of political parties in Pakistan.A paper presented in Cambridge Business and Economics Conference, Cambridge UK. http://www.gcbe.us/2012_CBEC/data/Bushra\%20Raza.doc

Rehman, A. U., Khan, A., \& Khan, B. (2017). Government-opposition relations during Benazir Bhutto's rule. Liberal Arts \& Social Sciences International Journal (LASSIJ), 1(2), 24-33. https://doi.org/10.47264/idea.lassij/1.2.3 
Rehman, O. (2016). Intra-party election and democracy in political parties of Pakistan. The Weekly Pakistan. https://www.the weeklypakistan.com/2016/03/25/ intra-partyelections-democracy-in-political-parties-of-Pakistan

Salih, M.A. M. (2006). The challenges of internal party democracy in Africa. In A Handbook on Working with Political Parties. UNDP. https://aceproject.org/ero-en/misc/undpa-handbook-on-working-with-political-parties

Sandri, G., \& Amjahad, A. (2015). Party membership and intra-party democracy: how do members react to organizational change within political parties? The case of Belgium. Partecipazione-e-Conflitto, 8(1),

190-214. https://core.ac.uk/download/pdf/41169245.pdf

Scarrow, S. (2005). Implementing intra-party democracy. In Johnston, M. (ed.). Political parties and democracy in theoretical perspectives: political finance policy, parties, and democratic development. National Democratic Institute of International Affairs (NDI). https://www.ndi.org/sites/default/files/1949_polpart_johnston_110105_5.pdf

The Constitution of Jamaat-e-Islami Pakistan. https://jamaat.org/

The Political Parties Order, 2002. Chief Executive's Order No. 18 of 2002. Government of Pakistan. https://www.ecp.gov.pk/frmGenericPage.aspx?PageID=3027

Vandeleene, A. (2014). Conceptualisation of intraparty democracy: the case of candidate selection in Belgium in 2014.A paper presented at the $8^{\text {th }}$ ECPR General Conference, 3-6 September 2014. Panel: S026: Elites and Citizens: Leadership, Responsiveness, or Distance? Glasgow, Scotland, UK.

Wauters, B. (2014). Democratising party leadership selection in Belgium: motivations and decision makers. Political Studies, 62, 61-80. https://doi.org/10.1111/1467$\underline{9248.12002}$

Yasin, A. (2017, May 22). PTI's Intra-party election not different from other parties. Daily Dawn. https://www.dawn.com/news/1335137 